\title{
ТИПЫ, РАЗМЕЩЕНИЕ И ПЕРСПЕКТИВЫ ПАЛЕОГЕНОВЫХ И НЕОГЕНОВЫХ РОССЫПЕЙ ЗОЛОТА В ЗАПАДНО-КАЛБИНСКОМ ЗОЛОТОНОСНОМ РАЙОНЕ (ВОСТОЧНЫЙ КАЗАХСТАН)
}

\author{
Третьяков Александр Валентинович1, \\ alextret_1210@mail.ru
}

\author{
Нигматова Саида Араповна', \\ nigmatova@mail.ru
}

\author{
Габитова Умиль Булатовна', \\ umil@bk.ru \\ 1 Университет Сатпаев, Казахстан, \\ 050010, Алматы, ул. Кабанбай батыра, 69.
}

\begin{abstract}
Актуальность исследования обусловлена необходимостью расширения сырьевой базы золотодобывающих предприятий Казахстана и научного обоснования перспектив вовлечения в эксплуатацию палеогеновых и неогеновых россыпных месторождений золота, условия формирования и закономерности размещения которых до настоящего времени не получили всесторонней оценки, хотя их продуктивность многократно превосходит потенциал россыпей четвертичного возраста.

Цель: укрепление сырьевой базы россыпного золота Республики Казахстан и повышение эфффективности ее освоения за счет изучения палеогеографических, палеоклиматических и неотектонических условий локализации россыпей кайнозойского возраста и уточнения критериев их поиска на площади Западно-Калбинского золотоносного района в Восточном Казахстане. Объекты: палеоген-неогеновые россыпи золота, древние россыпелокализующие элементы рельефа и вмещающие отложения. Методы: сбор и анализ имеющихся данных по россыпям золота палеогенового и неогенового возраста, распределению и формационной принадлежности золоторудных объектов; уточнение параметров древних долин и внутригорных впадин путем дешифрирования космических снимков; проведение геолого-геоморфологических наблюдений; составление карты россыпной золотоносности на геоморфологической основе и реконструкция геоморфологической зональности; картирование палеогеновых и неогеновых отложений, изучение их золотоносности, детальное комплексное изучение наиболее полных разрезов с отбором проб.

Результаты. Установлено, что россыпи палеогенового и неогенового возраста локализуются в древних долинах и впадинах, период их формирования охватывал длительный промежуток времени - от олигоцена до плиоцена. По генезису среди них выделены аллювиальные, аллювиально-пролювиальные и пролювиальные, в том числе локализованные во впадинах большеобъемные аллювиально-пролювиальные россыпи с преобладанием мелкого и тонкого золота. Основной закономерностью размещения палеоген-неогеновых россыпей является их пространственно-парагенетическая связь с коренными источниками, локальная геоморфологическая зональность определяет геолого-геоморфологические типы россыпей.
\end{abstract}

\section{Ключевые слова:}

Палеогеновые и неогеновые россыпи золота, древние долины, древние впадины, погребенные россыпи, Западно-Калбинский золотоносный район.

\section{Введение}

В настоящее время в Казахстане проводится интенсификация золотодобывающей отрасли. Эта задача определяет необходимость изучения и освоения разнотипных золотых месторождений, в том числе россыпных. Особого внимания заслуживают древние - палеогеновые и неогеновые - россыпи золота на территории Западно-Калбинской золотоносной зоны, входящей в состав Восточно-Казахстанского золотоносного пояса (рис. 1).

Западно-Калбинская золотоносная зона, пространственно совпадающая с центральной частью Западно-Калба-Коксентауской (ЗКК) зоны, имеет северо-западное простирание при протяженности более 300 км, ее ширина от 80 до 150 км. Северовосточной границей является Теректинский, юговосточной - Нарымский, юго-западной - ЧарскоГорностаевский глубинные разломы [2]. Структурное основание ЗКК разбито на тектонические блоки, мощность терригенного слоя в которых различна и изменяется от 5,5 до 9,8 км [3].

\section{Методика исследований}

Основными методами исследования являются сбор и анализ имеющихся данных по россыпям золота палеогенового и неогенового возраста, распределению и формационной принадлежности золоторудных объектов; уточнение параметров древних долин и внутригорных впадин путем дешифрирования космических снимков; проведение геолого-геоморфологических наблюдений, составление карты россыпной золотоносности на геоморфологической основе, реконструкция геоморфологической зональности, картирование палеогеновых и неогеновых отложений, изучение их золотоносности, детальное комплексное изучение наиболее полных разрезов с отбором проб.

\section{Основные черты геологического строения}

По данным предшествующих исследователей [2], ЗКК имеет следующее геологическое строение.

В нижней части разреза отложений палеозоя залегает алевролитовая аспидная формация раннегосреднего фамена мощностью 300 м. Ее перекрывает 
базальтовая известняково-терригенно-кремнистая формация фамена - позднего турне мощностью 1500 м. Вышележащие ранневизейские образования представлены известняково-песчаниково-алевролитовой формацией мощностью 300 м. После внутривизейского перерыва образовалась флишоидная углеродистоизвестковисто-терригенная формация среднеговерхнего визе мощностью 500 м. Последние с размывом перекрываются граувакковой алевролитопесчаниковой с олистостромами формацией серпуховского яруса нижнего карбона мощностью до 1400 м. Описанные выше образования ранней стадии герцинид со структурным несогласием перекрыты осадками средней стадии герцинского цикла, представленными лимническими, часто угленосными молассами буконьской и бакырчикской свит среднеговерхнего карбона мощностью 1000 м.

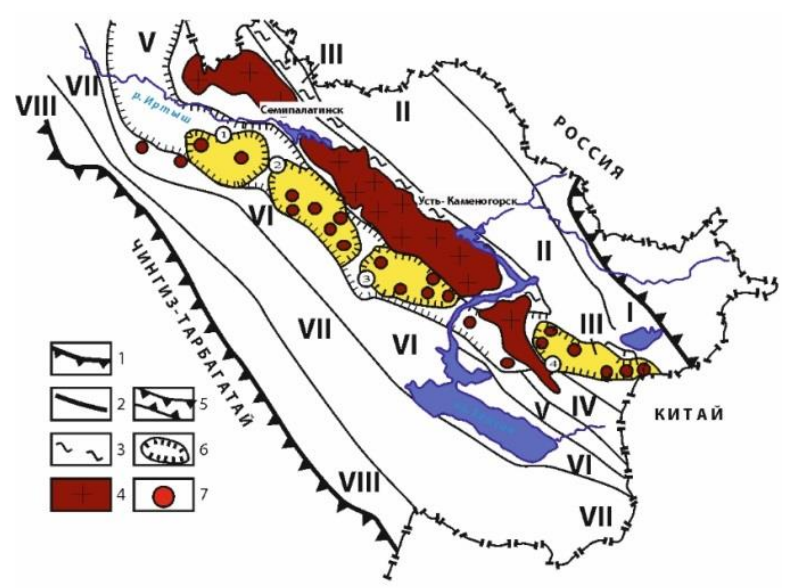

Рис. 1. Позиция Восточно-Казахстанского золотоносного пояса в структурах Большого Алтая (по [1]): 1 - границь Большого Алтая; 2 - границь металлогенических зон; 3 - Иртышская зона смятия; 4 - Калба-Нарымский гранитоидный пояс; 5 - Восточно-Казахстанский золоторудный пояс; 6 - рудные районы (1 - Мукурский, 2 Бакырчикский, 3 - Кулуджунский, 4 - Южсноалтайский); 7 - золоторудные месторождения. Структурные зоны: I - БелоубинскоСарымсактинско-Куртинская; II - Рудноалтайско-Ашалинская; III - Иртыли-Фуюньская; IV Калба-Нарым-Бурчумская; IV - Западно-КалбаКоксентауская; VI - Жарма-Саур-Харатунгская VII - Сериктас-Сарсазан-Кобукская; VIII - Чингиз-Тарбагатайская

Fig. 1. Layout of the East Kazakhstan gold belt in the structure of the Big Altai (Bol'shoy Altai) (according to [1]). Legend: 1 - the boundaries of Big Altai; 2 boundaries of metallogenic zones; 3 - Irtysh collapse zone; 4 - Kalba-Narym granitoid belt; 5 East Kazakhstan gold belt; 6 - ore areas (1 Mukursky, 2 - Bakyrchik, 3 - Kuludzhunsky, 4 South Altai); 7 - gold deposits. Structural zones: IBeloubinsko-Sarymsakta-Kurtin; II - Rudno-AltaiAshalinsk; III - Irtysh-Fuyunskaya; IV - KalbaNarym-Burchumskaya; IV - West Kalba-Kokstau; VI - Zharma-Saur-Kharatung; VII - SeriktasSarsazan-Kobukskaya; VIII-Chingiz-Tarbagatai
По содержанию углеродистого вещества породы сопоставляются с умеренно углеродистой формацией с неравномерным распределением золота. По представлениям Х.А. Беспаева, Ю.С. Парилова [4], в неизмененных разностях терригенных отложений нижнекарбоновой аркалыкской свиты, среднекарбоновых буконьской свиты и серпуховского яруса среднее содержание золота составляет в среднем 3,1 мг/т.

Интрузивные образования разнообразны по составу и возрасту. Наиболее древними являются протрузии серпентинитов, приуроченные к зоне ЧарскоГорностаевского разлома. В девонское время произошло внедрение базитовых субвулканических тел и даек габбро-плагиогранитной формации. Средневерхнекарбоновое время ознаменовано проявлениями разнообразной гаммы интрузивных образований, с которыми связано формирование золоторудных месторождений.

Габбронорит-диабазовая формация (карабирюкский комплекс $\mathrm{C}_{2-3}$ ) сформирована в две фазы. Первая объединяет крупнозернистые оливиновые габбронориты, мелкозернистые габбронориты и габбродиабазы, вторая сложена крупно- и среднезернистыми габбродиоритами и диоритами. Измененные разности габброидов и диоритов (брекчирование, окварцевание и пиритизация) сопровождаются золотосульфидным оруденением [2, 4].

Плагиогранит-гранодиоритовая формация (кунушский комплекс, $\mathrm{C}_{3}$ ) широко развита. Комплекс представлен небольшими массивами штокообразной и дайкообразной формы размером 0,1-3 км²; массивы группируются в цепочки, а дайки образуют протяженные пояса. Комплекс представлен роговообманково-биотитовыми гранодиоритами и биотитовыми плагиогранитами [2, 4]. Породы комплекса геохимически специализированы на золото, по данным [4] его среднее содержание составляет 4,9 мг/т. С кунушским комплексом связано золото-кварцевое и золотосульфидно-кварцевое оруденение.

Пермское время ознаменовано формированием Калба-Нарымского пояса гранитоидных интрузий [2].

Пликативная структура ЗКК выражена северозападными крутыми линейными складками протяженностью до 15-50 км при ширине 3-10 км. Мелкая складчатость чаще изоклинальная, с опрокидыванием складок к юго-западу. Широким развитием пользуются разрывные нарушения. Глубинные разломы северо-западного направления протягиваются через всю территорию района и прослеживаются далеко за его пределы. Разломы северо-восточного простирания, поперечные относительно общего структурного плана, как и ортогональные нарушения, устанавливаются геофизическими методами и при дешифрировании космоснимков.

\section{Коренные источники россыпного золота}

В районе развиты кварцево-жильный и золотоарсенопирит-пиритовый типы золоторудных месторождений, на западном фланге развиты месторождения окисленных руд в корах выветривания [4]. 
Квариево-жильный золоторудный тип месторождений по условиям залегания рудных тел подразделяются на два подтипа.

Квариево-жильный подтип представлен разномасштабными жильными золото-кварцевыми и золото-кварц-сульфидными объектами, локализованными в осадочных и вулканогенно-осадочных толщах. Жилы существенно кварцевые, примесь - карбонат, серицит и сульфиды (до 3-7 \%). Рудные минералы: самородное золото, арсенопирит и пирит. В рудах преобладает свободное самородное золото (до 95 \%), размер зерен от 0,05 до 0,5 мм, редкие золотины достигают размера до 30 мм. В сульфидах содержится тонкодисперсное золото (10-20 мкм).

Квариево-прожилковый подтип представлен сериями кварцевых прожилков и штокверками в штоках и дайках диабазов, габбро-диабазов, плагиогранитов, гранодиоритов, плагиогранит-порфиров и кварцевых порфиров. Главные рудные минералы: пирит, халькопирит, галенит, сфалерит, шеелит и золото. Золото в рудах (до 95 \%) свободное, его гранулометрический состав аналогичен месторождениям кварцевожильного подтипа. На месторождении Баладжал отмечены случаи, когда маломощные (3-5 см) кварцевые прожилки на три четверти были сложены 3олотом.

Золото-арсенопирит-пиритовый тип месторождений зон является ведущим по масштабам коренных объектов. Рудные тела представляют собой лентообразные залежи прожилково-вкрапленного золотосульфидного оруденения, локализованные в метасоматически измененных породах. Протяженность рудных тел от 150 до 600 м, мощность - от 0,6 до 32,8 м. Основные минералы руд: пирит, арсенопирит и золото, второстепенные - антимонит, пирротин, марказит, халькопирит, галенит. Золото в рудах тонкодисперсное, ассоциированное в пирите и арсенопирите с размером вкраплений 0,1-29 мкм.

Россыпеобразующими коренными источниками являются объекты кварцево-жильного типа, содержащие до $95 \%$ свободного самородного золота, большая часть которого представлена россыпеобразующими классами крупности. По данным А.Ф. Коробейникова и др. [3], кварцево-жильные месторождения составляют 42,6 \%, прожилково-вкрапленные $22,6 \%$, золото-сульфидные - 35,8 \% от общего числа месторождений и рудопроявлений в районе. То есть к потенциальным россыпеобразователям относится $65,2 \%$ от всех золоторудных объектов района.

Путем совместного анализа данных о глубинах формирования золоторудных месторождений и денудационного среза за пострудный период авторами определен относительный эрозионный срез золоторудных объектов за неотектонический период.

По оценкам А.Ф. Коробейникова и др. [3], глубина формирования золото-кварцевых руд от палеоповерхности составляла от 0,6 до 3,2-3,5 км при вертикальном размахе оруденения от 0,4 до 2 км. Возраст золото-кварцевых месторождений оценивается ими как позднекаменноугольный. По представлениям
Г.Н. Щербы и др. [2], денудационный срез различных участков Западной Калбы за постгерцинское время варьирует от 1-2 до 4,5-6 км. Совместная интерпретация этих данных показывает, что осредненная величина денудационного среза месторождений золотокварцевой формации достигает 1,9-2,4 км. Это позволяет предполагать значительную эродированность россыпеобразующих золото-кварцевых объектов. Это подтверждается развитием околорудной пропилитизации на ряде золоторудных объектов, что по данным А.Ф. Коробейникова и др. [3] свидетельствует о нижнерудном эрозионном срезе этих рудных полей.

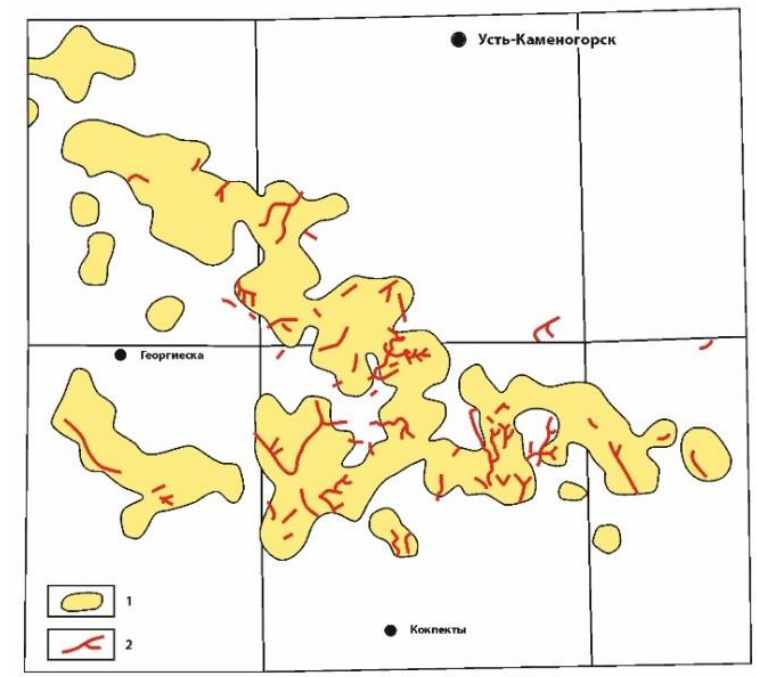

Pис. 2. Структура размещения золоторудных объектов юго-восточного фланга Западно-Калбинского района, положение россыпей золота различных геолого-генетических типов и возраста относительно нее (составил А.В. Третьяков): 1 ареал развития коренных источников; 2 - разнотипные и разновозрастные россыпи золота

Fig. 2. Localization of gold placers of various geologicalgenetic types and ages relative to motherlode structures in West Kalba. Composed by A.V. Tretyakov: 1 - motherlode development areas; 2 - gold placers

\section{Структура размещения коренных источников}

Золоторудные месторождения и проявления юговосточного фланга Западно-Калбинского золотоносного района сконцентрированы в поясе шириной от 12-15 до 70 км (рис. 2).

\section{Геоморфологические особенности}

Основными морфоструктурами района являются Калбинское нагорье и Чарско-Семипалатинская структурная перемычка.

Калбинское нагорье представляет собой единую сводовую структуру, осевая линия которой совпадает с орографической осью Калбинского хребта. По мнению В.С. Ерофеева [5], ее формирование обусловлено неотектоническим воздыманием поверхности выравнивания с амплитудой 600-1000 м. Юго-восточное крыло Калбинского нагорья осложнено Жолдыбайским и Баладжальским разломами с амплитудой сбросовых перемещений до 250-300 м, по которым 
образован Жолдыбайский грабен, выполненный кайнозойскими отложениями. Северо-западная часть Калбинского поднятия осложнена КиинсуТройницким прогибом, в пределах которого развиты реликты древней коры выветривания и кайнозойские отложения мощностью до 80-100 м.

Чарско-Семипалатинская структурная перемычка располагается между поднятиями Калбы и Тарбагатая, на юго-западе района. Ее северо-западный фланг представляет собой мелкосопочный пенеплен с древней долинной сетью, выполненной красноцветными глинами плиоцена, под которыми залегают аллювиальные галечники. В центральной части структуры располагается Чарская впадина, где мощность отложений кайнозойского и четвертичного возраста достигает 130 м. Юго-восточнее Чарской впадины, в области водораздела рек Чар и Кокпекты, описываемая структура осложнена поперечным поднятием, в пределах которого развит низкогорный мелкорасчлененный эрозионно-тектоногенный рельеф.

По комплексу ведущих рельефообразующих процессов рельеф Калбинского нагорья подразделяется на три типа: денудационный, эндогенно-экзогенный (эрозионно-тектоногенный, денудационно-тектоногенный, мелкосопочный) и аккумулятивный.

Денудационный рельеф - региональная поверхность выравнивания (РПВ), в различной степени расчлененная экзогенными процессами. По данным предшествующих исследователей [5], формирование РПВ происходило в две стадии. Первая охватывала длительный промежуток времени - с верхов раннего мела до раннего эоцена, вторая, менее продолжительная, - с верхнего эоцена до раннего олигоцена. К настоящему времени РПВ сохранилась в виде пологонаклонных фрагментов в приводораздельных частях нагорья. На юго-восточном фланге района абсолютные отметки РПВ максимальны и достигают 1400-1550 м, они понижаются в юго-восточном и северо-западном направлениях, где составляют 420-520 м. Фрагменты РПВ низких гипсометрических уровней перекрыты чехлом кайнозойских отложений, в пределах Киинсу-Тройницкого прогиба развиты коры выветривания.

Поднятие региона на неотектоническом этапе обусловило интенсификацию эрозии, расчленение РПВ и формирование денудационно-тектоногенного и эрозионно-тектоногенного типов рельефа.

Денудационно-тектоногенный рельеф, сформированный на участках относительно незначительной деструкции пенеплена, развит преимущественно на западном фланге, менее развит в центральных частях района. Он характеризуется слабой расчлененностью, пологими (от 5 до $10^{\circ}$ ) склонами, округлыми плавными очертаниями водоразделов. Относительные превышения не более 100 м.

Эрозионно-тектоногенный рельеф развит на восточном фланге района. Он гораздо более крутосклонный (до $25-30^{\circ}$ ), относительные превышения достигают 500 м. Основные формы - системы гряд со сглаженными или островершинными гребнями, раз- деленные в различной степени врезанными, иногда узкими речными долинами, имеющими на отдельных участках V-образный профиль.

Аккумулятивный рельеф, развитый в межгорных впадинах и долинах крупных рек, представлен днищами речных долин, фрагментами речных террас и аллювиально- пролювиальных равнин.

\section{Древние долины}

Специфическими формами рельефа, заслуживающими детального описания, являются древние долины [6]. Палеодолины различаются геоморфологическими особенностями, генезисом и возрастом, выполняющих их рыхлых отложений и россыпной золотоносностью.

По взаимоотношению с современной гидросетью они подразделяются на три типа:

a) развивающиеся унаследованно и используемые современными водотоками на всем их протяжении;

б) приподнятые отмершие, часто пересекаемые более молодыми эрозионными врезами с действующими водотоками;

в) погребенные отмершие в межгорных и грабенообразных впадинах.

В унаследованном режиме развивается подавляющее большинство древних долин крупных рек района. Отмершая приподнятая палеогидросеть развита на правом борту бассейна р. Былкылдак, в верховьях $\mathrm{p}$. Большой Чигилек. Отмершая погребенная гидросеть развита фрагментарно в пределах межгорных и грабенообразных впадин.

Динамический режим древних долин унаследованного развития оказывает наибольшее влияние на характер их россыпной золотоносности.

В перстративном режиме на протяжении четвертичного времени развивались палеодолины бассейнов рек Жанама, Былкылдак, Кызыл-Су, Балажал, верховья р. Чар, Даубай, Ашалы, Боко, Жинишке, Тамды. Долины этого типа широкие, днища их плоские, русловой врез обычно незначительный, террасы или отсутствуют, или их высота не превышает 2 м. По сохранности отложений неогена среди древних долин, развивающихся в перстативном режиме, выделяется два типа:

- c «откопанным» днищем, сложенным преимущественно породами палеозоя;

- c сохранившимися неогеновыми отложениями.

В древних долинах с «откопанным» днищем отложения неогена преимущественно уничтожены эрозией и сохранились фрагментарно в локальных депрессиях (верховья руч. Кожабулак, Елиген-Булак и др.). На некоторых участках (руч. Карамырза) древний аллювий сохранился фрагментарно в бортах долины, а на откопанном днище долины отмечаются многочисленные валуны кварца и, реже, гранитоидов, являющиеся его реликтами.

Инстративный режим развития речных долин, в зависимости от амплитуды неотектонических движений, носил умеренный либо интенсивный характер. 
В умеренном инстративном режиме на протяжении четвертичного времени развивались долины рек Агыныкатты, Чар (на ее нижнем отрезке), Сибинка, Шибынды, Жельдыарык. Долины рек, характеризующихся этим режимом развития, преимущественно террасированы, современные русла часто врезаны в поверхность более древних днищ на глубину до 20-30 м с образованием цокольных террас.

В интенсивном инстративном режиме развивались участки долин рек Большая Буконь, Малая Буконь, Большой Чегелек (выше их горного устья в пределах нагорья), а также долины рек Жумба, Кулуджун, Лайлы, Таргын и др. Долины этого типа ущельеобразные с крутыми, часто обрывистыми склонами. Днища их узкие, террасы отсутствуют, аллювий характеризуется высокой валунистостью.

Таким образом, древние долины Калбы разнообразны по условиям своего развития на неотектоническом этапе, что повлекло различия в особенностях и масштабах их россыпной золотоносности.

\section{Геоморфологическая зональность}

Описанные выше типы рельефа и палеодолин имеют зональное распространение, которое определяет размещение разнотипных россыпей. Авторами выделено три геоморфологических области.

Область интенсивных новейших поднятий, характеризующаяся развитием крутосклонного интенсивно расчлененного эрозионно-тектоногенного рельефа, располагается на восточном фланге района и охватывает осевую часть Калбинского нагорья. Фрагменты РПВ здесь располагаются на абсолютных высотах от 1200 до 1560 м. Они в значительной степени преобразованы в результате эрозионной деятельности. Речные долины (Жумба, Большая Буконь, Таргын, верховья реки Кулуджун, Лайлы и др.) развиваются в интенсивном инстративном режиме. Днища их узкие, глубина эрозионного вреза достигает 500 м.

Переходная зона, занимающая наиболее значительную площадь в центральной части района, характеризуется сочетанием всех типов эрозионнотектоногенного и денудационно-тектоногенного рельефа в комплексе с аккумулятивным рельефом внутригорных впадин. Фрагменты РПВ здесь в различной степени расчленены эрозионными процессами и располагаются преимущественно на абсолютных высотах от 600 до 1000 м. Эта зона характеризуется развитием разнообразных типов палеодолин, межгорных и грабенообразных впадин.

Область слабых и умеренных новейших поднятий, характеризующаяся развитием пологосклонного денудационно-тектоногенного рельефа, располагается на западном и юго-восточном флангах района. На западном фланге она охватывает левобережье рек Тамды и Жинишке, междуречье рек Чар и Кызылсу, а также бассейны рек Куйелы, Канайка, Уланка. Фрагменты РПВ здесь находятся на абсолютных высотах 500-600 м, реже - до 800 м. Они слабо расчленены эрозией, на отдельных участках перекрыты кайнозойскими отложениями.

\section{История развития рельефа}

Важным условием формирования разнообразных и масштабных россыпей является благоприятная история развития рельефа, детально изученная В.С. Ерофеевым [5]. По представлениям этого исследователя, началу неотектонических движений на территории Калбы предшествовала продолжительная - с верхов раннего мела до раннего эоцена - эпоха пенепленизации и интенсивного химического выветривания. В этот период формировались зоны окисления золоторудных месторождений, происходила дезинтеграция руд и высвобождение свободного самородного золота.

В среднем эоцене проявилась первая (южноалтайская) фаза тектонических движений, что привело к орографическому обособлению Калбинского нагорья, активизации эрозионно-денудационных процессов и появлению в коррелятных отложениях обломочных фаций. В описываемом районе россыпи этого возраста пока не установлены, в сопредельном же ЮжноАлтайском с этой эпохой связано формирование мощных толщ золотоносных кварцевых галечников.

Верхнеэоценовое-нижнеолигоценовое время характеризуется затуханием тектонических подвижек, на смену вертикальной эрозии пришли процессы выравнивания рельефа. Аллювиальные отложения характеризуются преобладанием перстративных фаций.

С началом среднего олигоцена связано проявление второй (нарымской) фазы тектонических движений, обусловившей более четкое оформление и эрозионное расчленение Калбинского поднятия. С этим временем связано заложение древней гидросети в пределах поднятия и грабенообразных впадин на его периферии. Реками переносилось значительное количество обломочного материала, в том числе продуктов разрушения окисленных частей золоторудных месторождений. Не исключено, что в этот период происходило инициальное россыпеобразование в Жолдыбайском грабене и древних долинах.

Аральское время (нижний-средний миоцен) характеризуется затуханием тектонических подвижек и изменением палеоклимата в сторону аридизации и похолодания. В Калбинском нагорье продолжались с тенденцией к затуханию эрозионные процессы, с которыми связано формирование золотоносных отложений аральской свиты в Жолдыбайском грабене.

В верхнем миоцене - нижнем плиоцене проявилась энергичная тарбагатайская фаза тектогенеза, приведшая к формированию на территории Калбы низких гор и возвышенных равнин. Климат был умеренно-теплым и сухим, эрозионная деятельность интенсивная в начальные периоды с тенденцией к затуханию. Об этом свидетельствует наличие в основании коррелятных отложений пачки песков и галечников, выделенных под названием «сарыбулакских» слоев. Перекрывающие их красноцветные песчанистые глины с редкими прослоями и линзами щебня (павлодарская свита) являются озерными отложениями [5].

Четвертичный этап характеризуется интенсивными подвижками по зонам активизированных разломов. 
С этим временем на отдельных участках связано заложение новой гидросети, имеющей секущее направление по отношению к древним долинам, а также формирование четвертичных россыпей золота - преимущественно за счет размыва древнего золотоносного аллювия, в меньшей степени - за счет поступления золота непосредственно из коренных источников.

Сходной историей развития рельефа характеризуются другие крупные золотороссыпные провинции мира. Так, в штате Виктория (Австралия) начало россыпеобразования связано с блоковыми неотектоническими поднятиями плиоценового возраста, что привело к размыву древних слабо золотоносных третичных отложений и накоплению золота в приоценовом аллювии [7]. Богатые россыпи Клондайка (Канада) также сформировались в результате неотектонического поднятия [8]. Формирование россыпей Калифорнии (США) началось в результате раннепалеогеновых неотектонических движений, которые привели к образованию олигоцен-миоценовых и плиоценовых россыпей, перекрытых затем вулканическими породами $[9,10]$.

Таким образом, характер развития рельефа описываемого района в кайнозойское- четвертичное время благоприятен для образования палеоген-неогеновых россыпей.

\section{Россыпная золотоносность}

Первые сведения о золотоносных россыпях Калбы относятся к 1800-м гг., когда Коммерции Советник Степан Попов сделал несколько заявок на золотые прииски. В последующие годы золотые прииски охватывали почти всю систему речек Калбы. Золотодобыча достигла расцвета к 1870-1880 гг., после чего она начинает падать и в период 1917-1920-х гг. практически прекратилась.

В последующем поисково-разведочные и тематические работы на россыпи проводились Е.М. Великовской (1938-1946 гг.); Н.И. Баженовым (1955 г.); В.И. Наливаевым (1970 г.); Г.К. Зубовым и др. (1971 г.); Э.В. Окуневым (1976 г.); Г.М. Козловским и др. (1977 г.), А.И. Демченко и др. (1982 г.); Е.М. Александровым и др. (1982 г.); Н.П. Введенской и др. (1983 г.); В.И. Кривцовым и др. (1985 г.); В.И. Наливаевым (1992 г.).

Подавляющее большинство этих исследований было ориентировано на изучение четвертичных неглубокозалегающих россыпей четвертичного возраста, только в работах Е.М. Великовской (1946г.) и В.И. Наливаева (1992 г.) отмечены значительные перспективы погребенных россыпей в древних долинах.

В период после 1995 г. частными недропользователями, при участии авторов данной статьи, выполнялись геологоразведочные и опытно-эксплуатационные работы.

\section{Перспективы древних россыпей золота}

Имеющиеся данные (В.И. Наливаев, 1992 г.) [6, 11] свидетельствуют о том, что продуктивность россыпей палеогенового и неогенового возраста многократно превосходит потенциал россыпей четвертичного возраста (табл. 1).
Таблица 1. Продуктивность разновозрастных россыпей на площади Западно- Калбинского района (по А.В. Третьякову, [6])

Table 1. Productivity of uneven-age placers on the area of the West Kalba district (according to A.V. Tretyakov, [6])

\begin{tabular}{|c|c|c|c|c|}
\hline \multirow[t]{2}{*}{$\begin{array}{c}\text { Показатели } \\
\text { Indicators }\end{array}$} & \multicolumn{4}{|c|}{$\begin{array}{c}\text { Запасы и прогнозные ресурсы золота } \\
\text { разновозрастных россыпей } \\
\text { Gold reserves and reserves uneven placers }\end{array}$} \\
\hline & $\mathrm{Pg}_{3}+\mathrm{N}_{1}$ & $\mathrm{~N}_{2}$ & $\mathrm{Q}$ & Total \\
\hline \multicolumn{5}{|c|}{ кг $/ \% ; \mathrm{kg} / \%$} \\
\hline $\begin{array}{l}\text { Прогнозная } \\
\text { оценка } \\
\text { Predictive } \\
\text { estimate }\end{array}$ & $37925 / 14,5$ & $216500 / 82,75$ & $7196 / 2,75$ & $261621 / 100$ \\
\hline $\begin{array}{l}\text { Апробиро- } \\
\text { ванные } \\
\text { запасы } \\
\text { Approved } \\
\text { stocks } \\
\end{array}$ & \multicolumn{2}{|c|}{$64,28 / 0,025$} & $2359,3 / 32,8$ & $2423,6 / 0,93$ \\
\hline
\end{tabular}

В Калифорнии (США) олигоценовые и миоценовые россыпи уникальны по параметрам: из них добыто 454 т золота с содержанием от 2 до 60 г/м ${ }^{3}$ [12]. Наиболее богатые россыпи штата Виктория (Австралия) сформированы в плиоцене [13], с палеоген-неогеновыми россыпями связан основной потенциал россыпей Аляски (США) и Клондайка (Канада) [14-18].

Изложенные данные о преобладающей продуктивности палеогеновых и неогеновых россыпей в мире подтверждают представления авторов о высоком россыпном потенциале Западно-Калбинского золотоносного района.

\section{Типы древних россыпей золота}

Анализ материалов предшествующих исследователей и результаты собственных наблюдений авторов [6, 11, 14-16] позволяют выделить следующие типы древних россыпей золота (табл. 2).

Как видно, период формирования древних россыпей охватывал длительный промежуток времени (от олигоцена до плиоцена).

Наиболее древние, олигоценовые, россыпные проявления изучены в погребенной долине р. Агыныкатты [15], рис. 3.

Олигоценовые отложения, залегающие в основании разреза, сложены серыми галечниками, заполнитель песчано-глинистый с синеватым оттенком. Галька средней окатанности представлена кварцем, интенсивно сульфидизированными (пирит, марказит) и разложенными хлорит-серицитовыми сланцами.

Марказит образует кристаллические агрегаты с тонкошестоватым и радиально-лучистым строением размером от 20 кмк до 1 мм; пирит представлен кристаллическими формами - октаэдрами и их сростками размером от 75 до 100 кмк, преобладающая часть сульфидов является новообразованными. Путем химического разложения марказита и пирита было вскрыто самородное золото. Золотины имеют угловато-комковидную (45 \%), пластинчатую (30 \%) и изометричную (25\%) форму. Средний размер золотин $45 \times 90 \times 140$ мкм, минимальный $-7 \times 14 \times 30$ мкм, максимальный $-42 \times 25 \times 280$ мкм. Морфология и отпечат- 
Известия Томского политехнического университета. Инжиниринг георесурсов. 2020. Т. 331. № 4. 156-169 Третьяков А.В., Нигматова С.А., Габитова У.Б. Типы, размещение и перспективы палеогеновых и неогеновых россыпей золота ...

ки на поверхности золотин показывают, что ориентировочно $10 \%$ золотин являются гипергенными, сформированными сингенетично с сульфидами; остальное золото является кластогенным.

Таблица 2. Типь древних россыпей золота Западно-Калбинского района и условия их локализации

Table 2. Types of ancient gold placers in the West Kalbinsky district and conditions for their localization

\begin{tabular}{|c|c|c|}
\hline $\begin{array}{l}\text { Boзраст } \\
\text { Age }\end{array}$ & $\begin{array}{l}\text { Генетический тип } \\
\text { Genetic type }\end{array}$ & $\begin{array}{c}\text { Геолого-геоморфологические условия локализации } \\
\text { Geological and geomorphological localization conditions }\end{array}$ \\
\hline $\begin{array}{l}\text { Олигоцен } \\
\text { Oligocene }\end{array}$ & $\begin{array}{l}\text { Аллювиальные } \\
\text { Alluvial }\end{array}$ & $\begin{array}{l}\text { В основании разреза аллювия древних долин } \\
\text { In the base of the alluvium section of the ancient valleys }\end{array}$ \\
\hline $\begin{array}{l}\text { Миоцен } \\
\text { Miocene }\end{array}$ & $\begin{array}{l}\text { Аллювиально-пролювиальные } \\
\text { Alluvial-proluvial }\end{array}$ & $\begin{array}{l}\text { Погребенные в грабенообразных впадинах } \\
\text { Buried in graben-shaped depressions }\end{array}$ \\
\hline $\begin{array}{l}\text { Плиоцен } \\
\text { Pliocene }\end{array}$ & $\begin{array}{l}\text { - Аллювиально-пролювиальные } \\
\text { Аlluvial-proluvial } \\
\text { - Пролювиальные } \\
\text { Proluvial } \\
\text { - Аллювиальные } \\
\text { Аlluvial } \\
\text { - Аллювиальные, аллювиально-пролювиальные боль- } \\
\text { шеобъемные с мелким и тонким золотом (прогнози- } \\
\text { руются) } \\
\text { Alluvial, alluvial-proluvial large with small and thin } \\
\text { gold (predicted) }\end{array}$ & $\begin{array}{l}\text { - Погребенные в грабенообразных впадинах } \\
\text { Buried in graben-shaped depressions } \\
\text { - Погребенные в древних логах } \\
\text { Buried in ancient logs } \\
\text { - Погребенные в палеодолинах унаследованного развития } \\
\text { Buried in paleo-valleys of inherited development } \\
\text { - Ocraточные на высоких цокольных террасах } \\
\text { Residual on high ground terraces } \\
\text { - В отмерших приподнятых палеодолинах } \\
\text { Buried in dead raised paleo-valleys } \\
\text { - Погребенные во внутригорных и грабенообразных впадинах } \\
\text { Buried in dead raised paleo-valleys }\end{array}$ \\
\hline
\end{tabular}

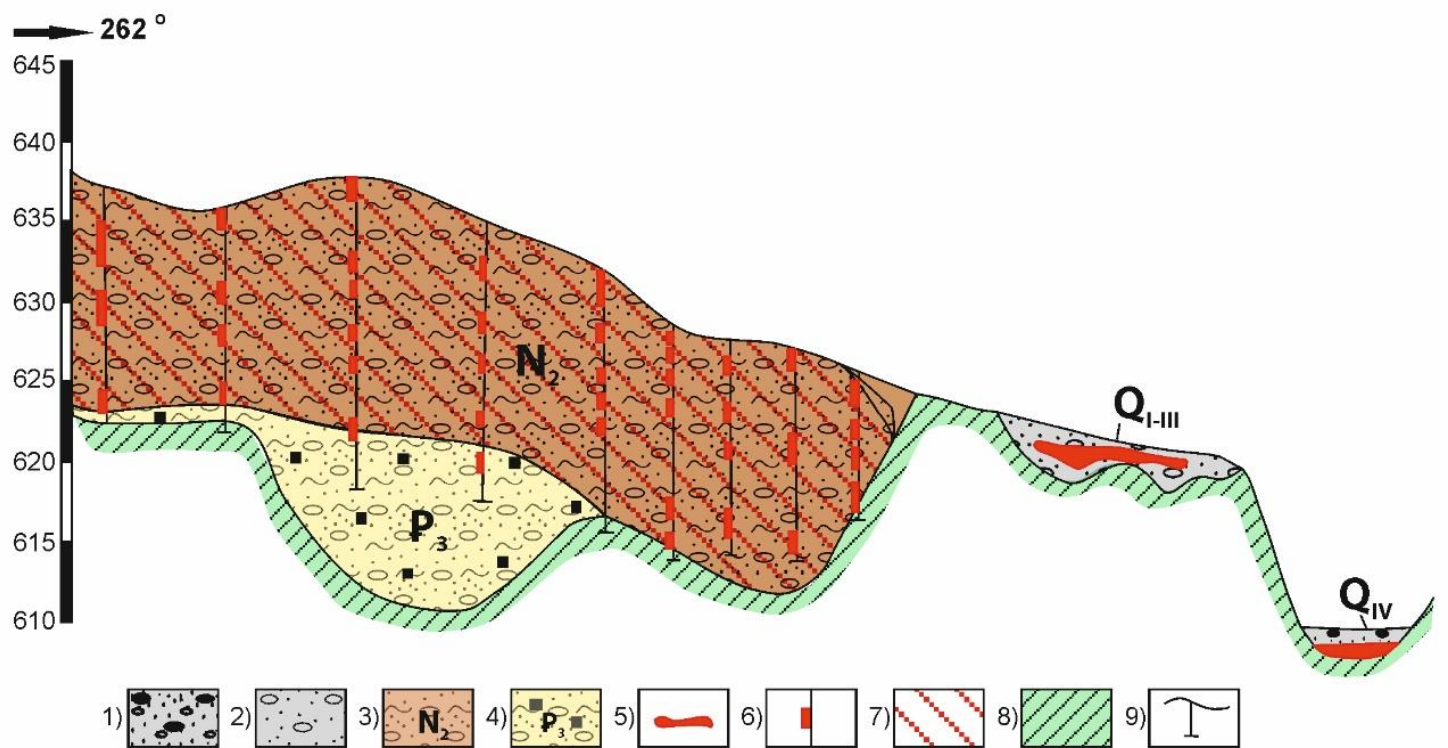

Рис. 3. Геологический разрез отложений долины р. Агыныкатты (составил А.В. Третьяков [15]): 1-4 - аллювиальные отложения: 1 - голоченовые; 2 - средне-верхнечетвертичные; 3 - плиоченовые (сарыбулакские слои), 4 - олигоченовые (ашутасская свита); 5 - россыпи в четвертичном аллювии; 6 - золотоносные интерваль разреза плиоценовых и олигоценовых отложений; 7 - плиоценовые отложения, перспективные на выявление большеобъемной россыпи с мелким и тонким золотом; 8 - породы плотика; 9 - скважины

Fig. 3. Geological section of deposits of the Agynykatty river valley (composed by A.V. Tretyakov [15]): 1-4 - alluvial deposits: 1 - Holocene age, 2 -Mid-upper Quaternary age, 3 - Pliocene age (Sary-Bulak layers), 4 - Oligocene age (the Ashu-Tassuite), 5 - Terracean driver bed placers in the Quaternary alluvium; 6 - gold-bearing intervals of the Pliocene-Oligocene deposit section; 7 - Pliocene deposit section intervals, promising large-volume placers with fine-grained gold; 8 -Paleozoic placer bedrocks; 9 -wells

Пробирным анализом в обломочном материале класса $-7+2$ мм (36 \%) установлено содержание золота 2,0 г/т; в материале класса $-40+7$ мм $(12,6 \%)-$ 2,4 г/т. Золотоносность отложений «на массу» составляет 1,54 г/т.

Интерпретация полученных данных с учетом представлений В.С. Ерофеева [5] позволяет параллелизовать описанные отложения с ашутасской свитой олигоценового возраста.
В миоченовое время сформированы аллювиальнопролювиальные погребенные россыпи грабенообразных впадин. Они выявлены в Жолдыбайском грабене, где общая мощность отложений достигает 80 м. В основании разреза развиты щебенисто-глинистые коры выветривания (1,0-3,5 м). Выше залегают отложения аральской свиты миоцена, представленные светло-зелеными, зеленовато-серыми, пестроцветными запесоченными глинами с прослоями и линзами 
песков и гравийно-галечников (от 5 до 60 м). Их с размывом перекрывают отложения павлодарской свиты плицена - запесоченные красно-бурые, коричневые глины с прослоями и линзами песков и гравийно-галечников мощностью от 0 до 29 м. Четвертичные отложения - суглинки со щебнем, глины, пески, галечники и валунно-галечники - от 2 до 8 м.

Россыпная золотоносность отложений аральской свиты установлена в погребенной палеодолине p. Малая Буконь [6], рис. 4. Золотоносный пласт спаевой, мощность торфов достигает 20-27 м. Мощность горизонта аллювия, вмещающего продуктивный пласт, - 5,5-6,0 м, мощность пласта - 1,43 м. Ширина контура россыпи не менее 300 м. Содержание золота в пласте варьирует от 1312 до $5153 \mathrm{мг} / \mathrm{M}^{3}$, в среднем $5074 \mathrm{M \Gamma} / \mathrm{M}^{3}$.

В плиоченовое время формировались аллювиально-пролювиальные россыпи во впадинах, аллювиальные, аллювиально-пролювиальные и пролювиальные россыпи в древних долинах и логах.

Аллювиально-пролювиальные погребенные россыпи впадин известны в Жолдыбайском грабене и древней грабенообразной долине ручья Бюкуй.

В Жолдыбайском грабене, в долине ручья Сухой Майкалган, на глубине 16 м под толщей глин павлодарской свиты вскрыт горизонт гравелистых песков мощностью до 4,0 м, залегающий на коренном плотике (Э.В. Окунев и др., 1976 г.). В подошве аллювиальных отложений установлено содержание золота

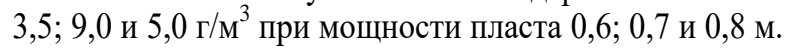

Мощность песков составляет 0,7 м, среднее содержание золота на пласт $-5800 \mathrm{Mr} / \mathrm{m}^{3}$.

В долине р. Бюкуй скважинами ударно-канатного бурения (УКБ) вскрыта погребенная грабенообразная долина [16], выполненная отложениями плиоценового возраста (рис. 5).

В отложениях павлодарской свиты содержание золота достигает 519 мг/м3. Под ними вскрыта толща коричневых запесоченных глин с прослоями гравийников и песков («сарыбулакские слои» в понимании [5]), на которой красноцветные глины залегают с размывом. Золотоносность «сарыбулакских» отложений установлена в орографически правом тальвеге (рис. 5). Большинством скважин вскрыты маломощные

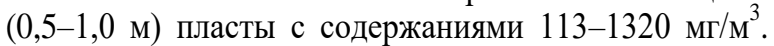
Одной скважиной выявлена россыпная струя шириной 80 м. Мощность торфов составляет 12 м, мощность песков 8 м, максимальное содержание золота достигает $1761 \mathrm{мг} / \mathrm{M}^{3}$, составляя в среднем $621 \mathrm{мг} / \mathrm{m}^{3}$. Очевидно, эта струя приурочена к эрозионному врезу второй половины «сарыбулакского» времени в «сарыбулакские» же отложения и сформирована в результате аккумуляции золота, заимствованного из одновозрастного промежуточного коллектора - отложений «сарыбулакских» слоев.

Аллювиальные россыпи древней гидросети, в том числе отмершей приподнятой, приурочены к «сарыбуласким» галечникам, обнажающимся на поверхности либо погребенными под толщей красноцветных глин павлодарской свиты.

3

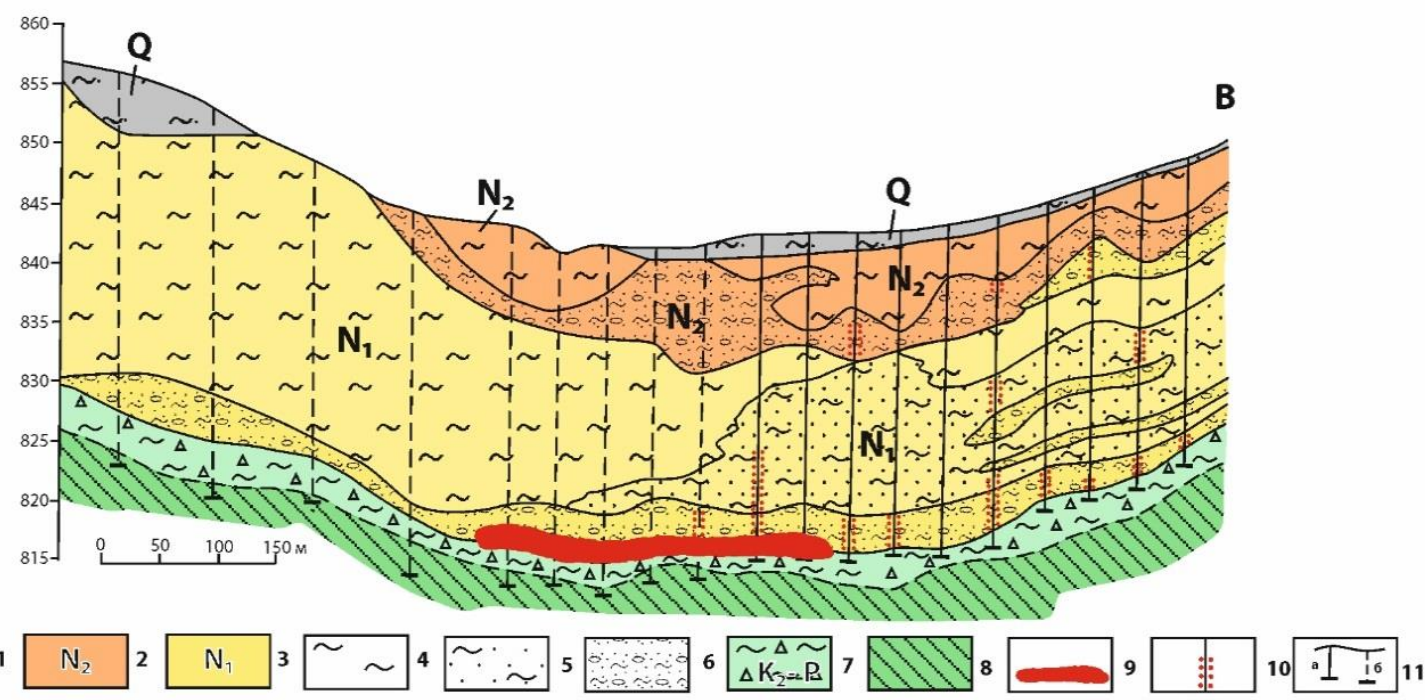

Рис. 4. Геологический разрез участка Мало-Буконьский (составил А.В. Третьяков с использованием материалов ПГО «Востказгеология»): 1 - четвертичные отложения (суглинки); 2, 3 - неогеновые отложения: 2 - миоцен, аральская свита, 3 - плиоцен; 4 - глины; 5 - пески глинистые; 6 - гравийно-галечники; 7 - щебнистоглинистая кора выветривания мел-палеогенового возраста; 8 - палеозойские породы плотика; 9 - продуктивный пласт россыпи; 10 - интервалы с незначительным весовым содержанием золота; 11 - скважины: а) ударно-канатного бурения, б) бурения комплексом гидровыноса керна

Fig. 4. Geological section of the Small-Bukon plot (composed by A.V. Tretyakov using materials of «PGO Vostokkazgeologia»): 1 -Quaternary rubble-loam; 2, 3 -Neogene deposits: 2 -Miocene, Aral suite, 3 -Pliocene; 4 -clays; gravel rock; 5 - pelitic sands; 6 - gravel and shingle; 7 - rubble-loam residuum; 8 -Paleozoic bedrocks; 9 - producing formation; 10 - intervals with miniscule weight content of gold; 11 - boreholes: a) shock-rope drilling, b) drilling with a core hydraulic removal complex 


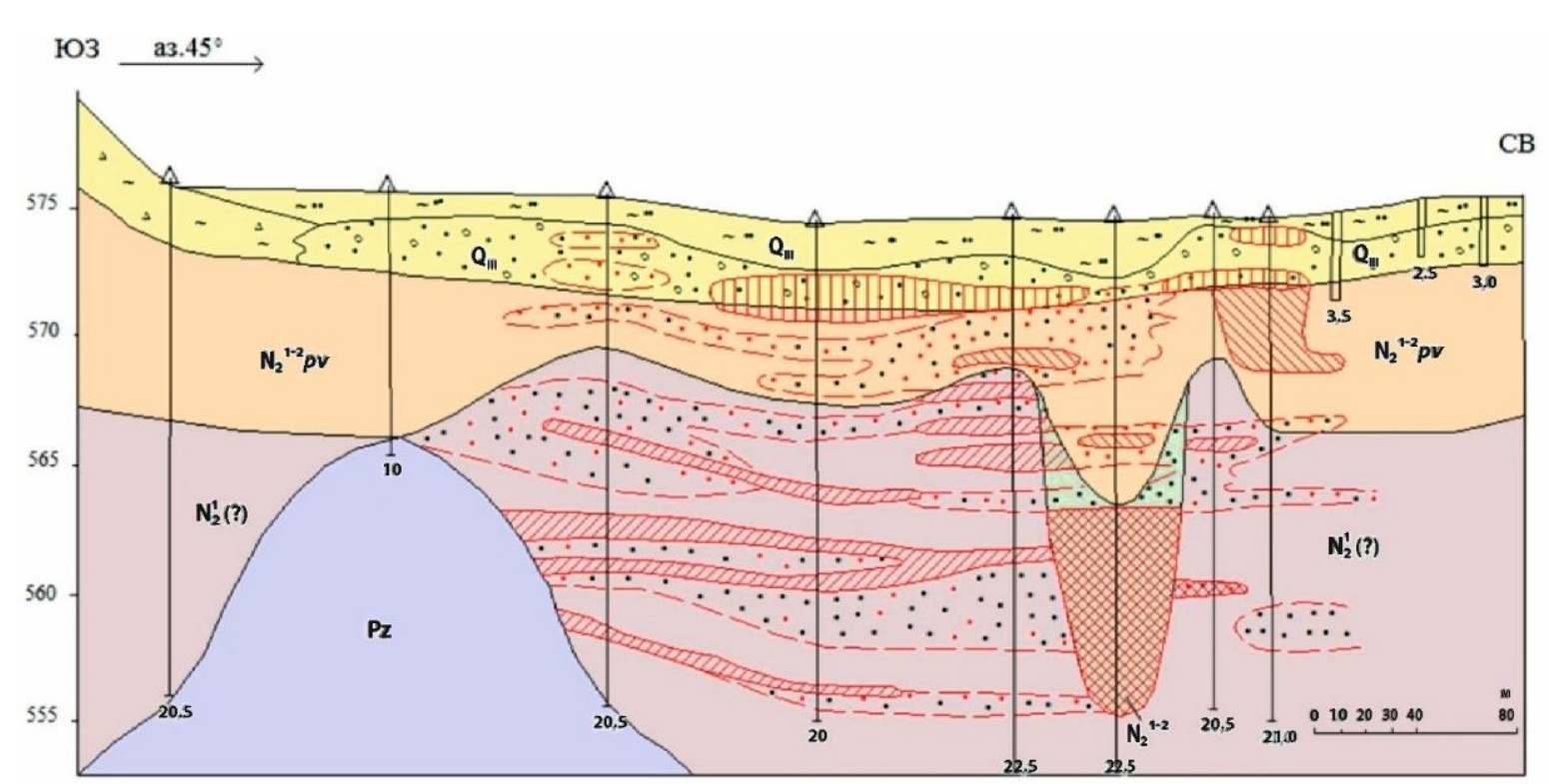

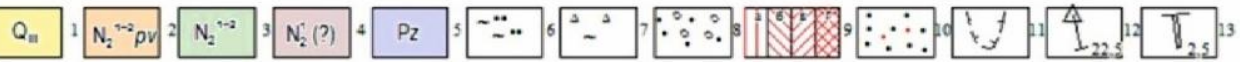

Рис. 5. Геологический разрез грабенообразной долины р. Бюкуй: 1 - четвертичные галечники, супеси, суглинки; 2 неогеновая система, плиоцен: павлодарская свита: глины красные, редко с включениями гальки и щебня; 3 переотложенные запесоченные глины сарыбулакских слоев; 4 - неогеновая система, плиочен, сарыбулакские слои: глины запесоченные с линзами глинистых песков с мелкой галькой; 5 - палеозойские отложения; 6 - супеси; 7 - суглинки со щебнем; 8 - галечники; 9 - пласты с весовым содержанием золота: а) в четвертичных отложениях, б) в породах павлодарской свиты, в) в сарыбулакских слоях, г) в переотложенном материале сарыбулакских слоев; 10 - пласты со знаками золота в разновозрастных отложениях; 11 - эрозионный врез в сарыбулакские слои; 12 - скважины ударно-канатного бурения и их глубина, м; 13 - иурфы и их глубина, м

Fig. 5. Geological section of the graben-like Byukui river valley: 1 - upper Quaternary deposits (shingle, sand clay, loam with rubble); 2 - Pliocene, the Pavlodar suite (clays brick-red, sometimes with gravel and rubble); 3 - re-deposited material of Sary-Bulak layers; 4 - Pliocene, Sary-Bulak layers (oversand clays with interlayers of loamy sands with rubble and fine gravel); 5 - Paleozoic deposits undivided; 6 -loamy sand; 7 -loam with rubble; 8 - shingle; 9 gold-bearing layers with weight content of gold in: a) Quaternary deposits, 6) deposits of Pavlodar suite, в) deposits of Sary-Bulak layers, 2) re-deposited material of Sary-Bulak layers; 10 - layers with indicative gold content in diverse-age deposits; 11 - limits of erosion cut into deposits of Sary-Bulak layers; 12 - cable drilling boreholes and their depths, $m ; 13$ - prospecting holes and their depths, $m$

Погребенные россыпи этого типа, где древний аллювий перекрыт глинами павлодарской свиты мощностью до 20-25 м, изучены в бассейне р. Былкылдак (В.И. Наливаев, 1992 г.). Здесь, в верховьях р. Сенташ, скважинами УКБ выявлена погребенная россыпь шириной 185 м при средней мощности пласта 1,2 м (рис. 6).

Содержание золота на пласт изменяется от 0,7 до $8,5 \mathrm{r} / \mathrm{M}^{3}$, составляя в среднем $3,37 \mathrm{r} / \mathrm{M}^{3}$. Поисковыми линиями (Н.П. Введенская, 1983 г.) эта погребенная россыпь прослежена вниз по долине на 11 км.

По данным Г.М. Козловского и др. (1977 г.), В.И Наливаева (1992 г.) золотоносный погребенный аллювий, залегающий под толщей красноцветных глин павлодарской свиты, развит также в долинах рек Чар, Балажал, Кызыл-Су, Даубай, ручьев Кожабулак, Елиген-Булак и др.

Древние аллювиальные россыпи, где плиоценовый аллювий обнажен на поверхности, развиты в орографически нижней части древней долины р. Агыныкатты (рис. 2). Верхние интервалы разреза (в интервале 0-17 м) сложены хорошо окатанными аллювиальными валунно-галечниками «сарыбулакских слоев» плиоценового возраста (по [5]). В составе обломочно- го материала отмечен кварц (до 20-25 \%), а также песчаники и алевролиты. Россыпной золотоносностью характеризуется весь разрез плиоценового аллювия, преобладает мелкое и тонкое пластинчатое и листовидное золото.

Остаточные аллювиальные россыпи известны в долине р. Карамырза. Здесь древний аллювий сохранился фрагментарно в бортах долины, а на откопанном днище долины многочисленны валуны кварца (до 0,7 м в поперечнике) и гранитоидов (до 0,5 м), являющиеся реликтами древнего размытого аллювия. Отложения, вмещающие россыпь, представлены суглинками со щебнем и включениями реликтовых валунов кварца. Распределение золота разной крупности в разрезе не характерно для аллювиальных россыпей: наиболее крупные золотины и самородки приурочены к верхней и средней частям разреза, золото мелких и пылевидных классов образует ореол в кровле и подошве пласта. Аналогичное строение описано для россыпей бассейна реки Вулшед-Крик (штат Виктория, Австралия) [13]. По данным этого исследователя, в части этих россыпей обломочный материал был полностью вынесен в результате размыва, а золото сохранилось в верхней части плотика. 


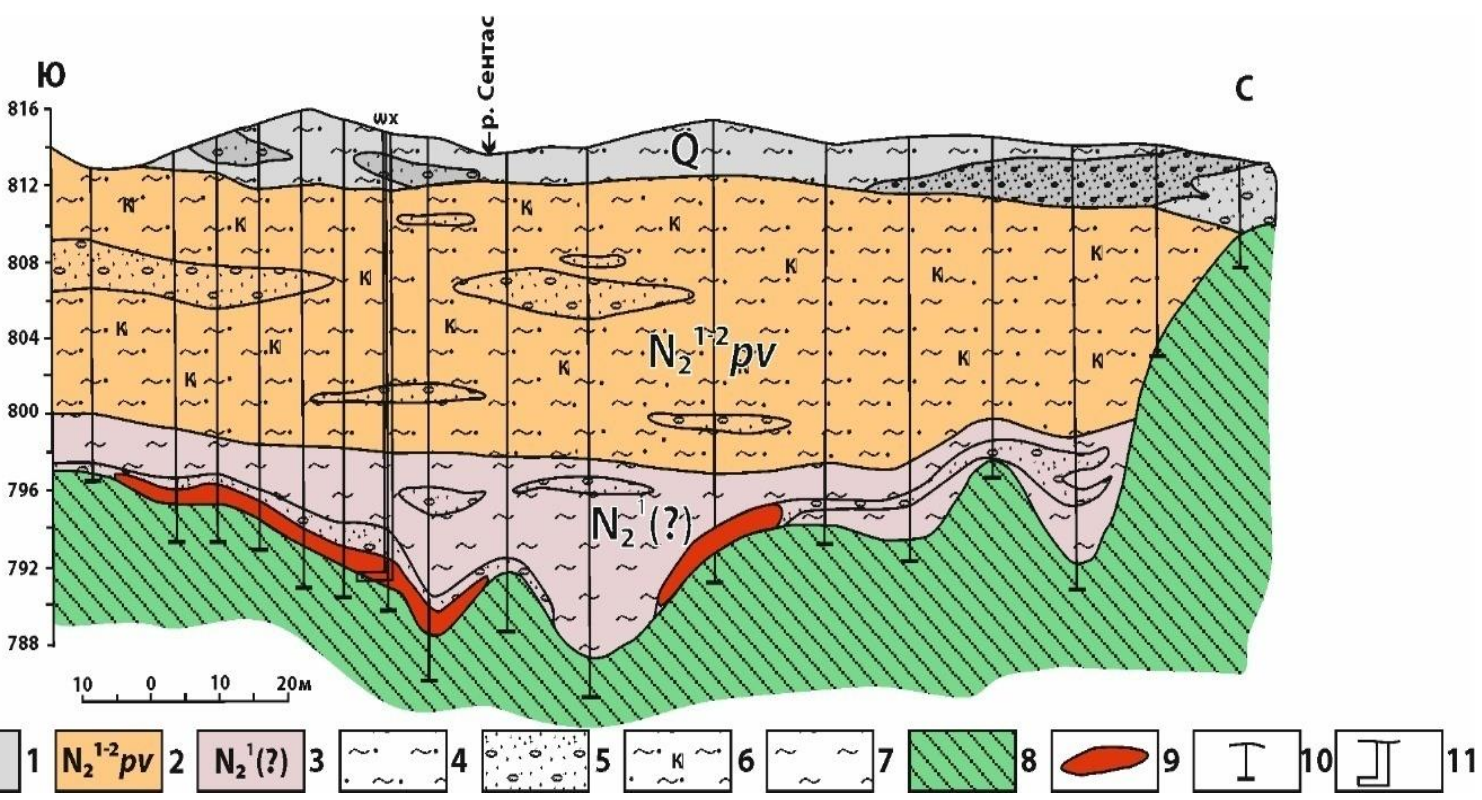

Рис. 6. Геологический разрез погребенной россыпи долины р. Сенташ (бассейн р. Былкылдак, составлено по материалам ГОКа «Алтайзолото»): 1 - четвертичные отложения; 2, 3 - неогеновые отложения: 2 - павлодарская свита, 3 - «сарыбулакские слои»; 4 - суглинки; 5 - галечники, гравийно-галечники; 6- глины бурые, буровато-коричневые песчанистые карбонатизированные; 7 - глины серые запесоченные; 8 - песчаники и алевролиты палеозоя; 9 - золотоносный пласт; 10 - скважины ударно-канатного бурения; 11 - шахта периода XIX в.

Fig. 6. Geological section of a buried placer in the Sentash river valley (Bylkyldak river basin based on materials of «the GOK Altai Zoloto»): 1 - Quaternary deposits; 2, 3 - Neogene deposits: 2 - Pavlodar formation, 3 - «Sarybulak beds»; 4 - loams; 5 - pebbles, gravel-pebbles; 6 - brown, brownish sandy carbonated clayey clay; 7 - sand-gray clay; 8 - Paleozoic sandstones and siltstones; 9 - gold-bearing layer; 10 - shock-rope drilling; 11 - mine period of the XIX century

Аллювиальные, аллювиально-пролювиальнье большеобъемные россыпи с мелким и тонким золотом прогнозируются авторами [6] в бассейнах рек Чар, Агыныкатты, Батпак-Булак, Былкылдак и в Жолдыбайском грабене на основании совместного анализа положения этих участков в структуре коренных источников, особенностей их геологогеоморфологического строения, анализа истории развития гидросети и связанной с ней эволюции россыпеобразования как аналоги россыпей Большой Куранах в Якутии, Нагиминской и Петровской в Амурской области [17]. Их обнаружение прогнозируется в межгорных (участки Средний Былкылдак, Нижнечарский) и грабенообразных (участки Сухой Майкалган, Малобуконьский) впадинах. В сопредельных районах Рудного Алтая на вероятность формирования таких россыпей указывают в [18].

Принципиально механизм формирования и геолого-геоморфологические условия локализации этих россыпей (за счет поступления золота из горного обрамления впадин) сходны с таковым прибрежноморских россыпей. Так, в золотороссыпном узле Ном (Аляска) богатые аллювиальные россыпи горного обрамления являлись источником масштабных прибрежно-морских россыпей, из которых добыто не менее 188 т золота [19]. Благоприятность условий для накопления тонкого золота в периферических частях «сухих» дельт (конусов выноса современных и древних рек) описана также в [20].

\section{Закономерности размещения древних россыпей золота}

Главной закономерностью является наличие пространственно-парагенетической связи россыпей с коренными источниками - россыпи всех геологогеоморфологических типов и возраста тяготеют к внутренним частям и ближайшему обрамлению ареала развития коренных источников (рис. 2).

Геоморфологические закономерности локализации россыпей менее однозначны. Неоднократные фазы активизации эрозионно-тектонических процессов привели к размыву части россыпей и переотложению золота на сопредельных отрезках речных долин, часто в россыпях иного типа. Длительная в целом история россыпеобразования обусловила трансформацию геолого-геоморфологических типов россыпей, но не определила какой-либо геоморфологической ситуации, особо благоприятной для их концентрации.

Вместе с тем, локальная геоморфологическая 30нальность Западно-Калбинского района обусловила наличие закономерностей размещения разнотипных древних долин и впадин в геоморфологических зонах и как следствие - наличие закономерностей размещения разнотипных древних россыпей, которые известны в переходной геоморфологической зоне и зоне слабых и умеренных поднятий [6].

В переходной геоморфологической зоне развиты следующие типы рельефа: эрозионно-тектоногенный интенсивно расчлененный крутосклонный (отн. превышения до 300 м); эрозионно-тектоногенный рас- 
члененный мелкогривистый крутосклонный (отн. превышения до 150 м); денудационно-тектоногенный пологосклонный (отн. превышения не более 100 м); фрагменты располагаются РПВ на абс. высотах от 600 до 1225 м.

В этой зоне развиты все типы древних россыпелокализующих элементов рельефа: древние долины всех типов (отмершие приподнятые, отмершие погребенные, унаследованного развития, лога древней гидросети, внутригорные и грабенообразные впадины). Это обусловило формирование всего спектра древних россыпей: аллювиально-пролювиальных большеобъемных во впадинах, аллювиальных, в том числе погребенных, в разнотипных палеодолинах и древних логах.

В геоморфологической зоне слабых и умеренных поднятий развит денудационно-тектоногенный пологосклонный рельеф с относительными превышения не более 80 м и мелкосопочник; фрагменты РПВ располагаются на абсолютных высотах 500-600 м, на отдельных участках до 800 м. В этой зоне развиты древние долины и лога унаследованного развития и грабенообразные впадины, в которых выявлены погребенные россыпи в древних долинах и логах, прогнозируются аллювиально-пролювиальные большеобъемные россыпи в грабенообразных впадинах.

Как видно, наибольшим разнообразием древних россыпелокализующих элементов рельефа и, в связи

\section{СПИСОК ЛИТЕРАТУРЫ}

1. Дьячков Б.А., Омирсериков М.Ш., Сапаргалиев Е.М., Ойцева Т.А., Кузьмина О.Н., Зимановская Н.А. Научные основы разработки технологии прогнозно-поисковых работ// Инновации и перспективные технологии геологоразведочных работ в Казахстане: Материалы Международной научнопрактической конференции «Бекжановские чтения». - Алматы, 2017. - С. 21-26.

2. Щерба Г.Н., Дьячков Б.А., Нахтигаль Г.П. Металлогения Рудного Алтая и Калбы. - Алма-Ата: Изд-во «Наука», 1984. $240 \mathrm{c}$.

3. Коробейников А.Ф., Масленников В.В. Закономерности формирования и размещения месторождений благородных металлов Северо-Восточного Казахстана. - Томск: Изд-во Томского ун-та, 1994. - 337 с.

4. Беспаев Х.А., Парилов Ю.С. Западно-Калбинский золоторудный пояс (Восточный Казахстан). - Алматы: Изд-во «Комплекс», 2018. - $215 \mathrm{c}$.

5. Ерофеев В.С. Геологическая история южной периферии Алтая в палеогене и неогене. - Алма-Ата: Изд-во «Недра», 1969. $165 \mathrm{c}$.

6. Третьяков А.В. Формирование, закономерности размещения и перспективы россыпной золотоносности Востока Казахстана. - Алматы: Изд-во «Комплекс», 2009. - 260 с.

7. Dynn E.I. Geology of gold. - London: Charles Griffin and Co., Ltd., 1929. - 303 p.

8. Boyle R.W. The geochemistry of gold and its deposits (together with a chapter on geochemical prospecting for the element // Bulletin of the Geological Survey. - 1979. - № 280. - P. 15-35.

9. Alber I.P. A lithologic-tectonic framework for the metallogenic problems of California // Economic Geology. - 1981. - V. 76. № 4. - P. 765-790.

10. Burnett I.L. Gold mining in California // California-Geology 1985. - P. 158-196.

11. Третьяков А.В. Развитие представлений К.И. Сатпаева о перспективах древних россыпей золота в Казахстане // Иннова- с этим, перспективами палеогеновых и неогеновых россыпей характеризуется переходная зона.

Таким образом, распределение древних россыпей в Западно-Калбинском районе определяется их пространственно-парагенетической связью с коренными источниками, структура размещения которых определяет структуру размещения россыпей.

Геоморфологические закономерности обусловлены локальной геоморфологической зональностью и определяют геолого-геоморфологический тип россыпей.

\section{Выводы}

1. Продуктивность россыпей палеогенового и неогенового возраста многократно превосходит потенциал россыпей четвертичного возраста.

2. Палеоген-неогеновые россыпи локализованы в разнотипных древних долинах и впадинах.

3. Формирование древних россыпей в ЗападноКалбинском золотоносном районе происходило на протяжении длительного промежутка времени - с олигоцена по плиоцен, что обусловило многообразие их геолого-геоморфологических типов.

4. Основной закономерностью их размещения является пространственно-парагенетическая связь с коренными источниками, структура размещения которых определяет структуру размещения россыпей, в то время как локальная геоморфологическая зональность определяет геологогеоморфологические типы россыпей.

ционные технологии - ключ к успешному решению фундаментальных и прикладных задач в рудном и нефтегазовом секторах экономики Республики Казахстан: Труды Сатпаевских чтений. - 2019. - Т. 1. - С. 110-117.

12. Tarr W.A. Introductory economic geology. - New York; London: McGraw-Hill Book Company Inc., 1930. - 664 p.

13. Geology of Australian ore deposits. Mineralogy and Metallurgy Congress. 2nd ed. / Ed. by J. McAndrew. - Australia; New Zeeland, Melbourne, 1965. - V. 1. - P. 29-60.

14. Le Barge W., Naumov V.A. New results on the stratigraphy and placer gold potential of central Yukon // Yukon Exploration and Geology. - 2008. - V. 1. - P. 1-25.

15. Третьяков А.В., Перегудов В.В. Новые данные о золотоносности кайнозойских отложений древних долин Калбинского района // Геология и охрана недр. - 2016. - № 1. - С. 49-53.

16. Третьяков А.В., Медеуов М., Алимханов М.С. Россыпная золотоносность центральной части бассейна р. Бюкуй (Восточный Казахстан) // Геология и охрана недр. - 2018. № 3 (68). - С. 51-57.

17. Патык-Кара Н.Г. Многопластовые россыпи приразломных впадин // Россыпные месторождения России и других стран СНГ. - М.: Изд-во «Научный мир», 1997. - С. 92-98.

18. Тлеулес Н.Ж., Слямбаева А.А., Аналиева Б.Б. Золотоносные россыпи Южного Алтая и их оценка // Материалы международной научно-практической конференции, посвященной 120 летию К.И. Сатпаева. - Усть-Каменогорск, 12 апреля 2019. C. 160-163.

19. Nokleberg W.J., Bundtzen T.K., Berg H.C. Significant metalliferous lode deposits and placer districts of Alaska // United States Geological Survey Bulletin. - 1987. - № 1786. - P. 35-70.

20. Cook D.S., Rao P.D. Distribution, analysis, and recovery of fine gold from alluvial deposits. - Fairbanks: Mineral Industry Research Lab. and Department of Mineral Engineering, University of Alaska, 1973. - Report № 32. - 101 p.

Поступила 29.10.2019 2. 
Известия Томского политехнического университета. Инжиниринг георесурсов. 2020. Т. 331. № 4. 156-169

Третьяков А.В., Нигматова С.А., Габитова У.Б. Типы, размещение и перспективы палеогеновых и неогеновых россыпей золота ...

\section{Информация об авторах}

Tpemьяков A.B., доктор геолого-минералогических наук, главный научный сотрудник Института геологических наук им. К.И. Сатпаева, Университет Сатпаев.

Нигматова $\boldsymbol{C . A . , ~ д о к т о р ~ г е о л о г о - м и н е р а л о г и ч е с к и х ~ н а у к , ~ г л а в н ы и ̆ ~ н а у ч н ы и ̆ ~ с о т р у д н и к ~ И н с т и т у т а ~ г е о л о г и ч е - ~}$ ских наук им. К.И. Сатпаева, Университет Сатпаев.

Габитова У.Б., научный сотрудник Института геологических наук им. К.И. Сатпаева, Университет Сатпаев. 
UDC 553.411

\title{
TYPES, DISTRIBUTION AND PERSPECTIVES OF PALEOGENE AND NEOGENE ALLUVIAL GOLD IN WEST-KALBA GOLD-BEARING DISTRICT (EAST KAZAKHSTAN)
}

\author{
Alexander V. Tretyakov ${ }^{1}$ \\ alextret_1210@mail.ru
}

\author{
Saida A. Nigmatova ${ }^{1}$, \\ nigmatova@mail.ru \\ Umil B. Gabitova ${ }^{1}$, \\ umil@bk.ru \\ 1 Satpaev University, \\ 69, Kabanbai Batyr street, Almaty, 050010, Kazakhstan.
}

The relevance of the research is conditioned by the need to expand the raw mineral base of the gold-mining enterprises of the Republic of Kazakhstan and scientific substantiation of prospects of involvement into exploitation of Paleogene and Neogene alluvial gold deposits, their formation conditions and placement patterns not being comprehensively assessed so far, despite the fact of their productivity is a very large multiple of the potential of the Quaternary alluvial gold.

The aim of the research is to strengthen the raw mineral base of alluvial gold deposits of the Republic of Kazakhstan, increase its development efficacy on account of studies of the paleographic, paleoclimatic and neotectonic conditions of the Cenozoic placer localization and detailing the criteria of their research in the area of the West Kalba gold-bearing district, East Kazakhstan.

Objects: Paleogene and Neogene alluvial gold, the ancient placer-localising relief and hosting rocks.

Methods: analysis of the existing data on alluvial gold of the Paleogene and Neogene age, further elaboration of characteristics of ancient valleys and intermontane depressions by deciphering satellite images; carrying out the geological and geomorphological observation, mapping of the Paleogene and Neogene deposits, study of their gold-content, complex detailed study and sampling of the most complete sections.

Results. It is established that the Paleogene and Neogene alluvial gold is localized in ancient valleys and depressions, their formation period lasting the significant time interval, from the Oligocene to the Pliocene. They are represented by alluvial, alluvial-proluvial and proluvial placers, including the large-volume alluvial-proluvial placers, localized in depressions and dominated by small fine gold. The Paleogene and Neogene placers are distributed according to spatial-paragenetic relation with route sources, and their geological and geomorphological types are defined by the local geomorphological zonality.

Key words.

Paleogene and Neogene alluvial gold, ancient valleys, ancient depressions, buried placers, the West Kalba gold-bearing district.

\section{REFERENCE}

1. Dyachkov B.A., Omirserikov M.Sh., Sapargaliev E.M., Oytseva T.A., Kuzmina O.N., Zemanovskaya N.A. Nauchnye osnovy razrabotki tekhnologii prognozno-poiskovykh rabot [Scientific basis for development of technology of forecasting and prospecting]. Innovatsii $i$ perspektivnye tekhnologii geologorazvedochnykh rabot $v$ Kazakhstane. Materialy Mezhdunarodnoy nauchnoprakticheskoy konferentsii «Bekzhanovskie chteniya» [Novation and prospective techniques of exploration in Kazakhstan. Proc. of the International scientific conference]. Almaty, 2017. pp. 21-26.

2. Shcherba G.N., Dyachkov B.A., Nakhtigal G.P. Metallogeniya Rudnogo Altaya $i$ Kalby [Metallogeny of Ore Altai and Kalba]. Alma-Ata, Nauka Publ., 1984. 240 p.

3. Korobeynikov A.F., Maslennikov V.V. Zakonomernosti formirovaniya $i$ razmeshcheniya mestorozhdeniy blagorodnykh metallov Severo-Vostochnogo Kazakhstana [Laws of formation and location of deposits of noble metals of North-Eastern Kazakhstan]. Tomsk, Tomsk University Publ., 1994. 337 p.

4. Bespaev Kh.A., Parilov Yu.S. Zapadno-Kalbinskiy zolotorudny poyas (Vostochny Kazakhstan) [The West Kalbin gold belt (Eastern Kazakhstan)]. Almaty, Kompleks Publ., 2018. 215 p.

5. Erofeev V.S. Geologicheskaya istoriva yuzhnoy periferii Altava v paleogene i neogene [Geological history of the southern periphery of Altai in the Paleogene]. Alma-Ata, Nedra publ., 1969. 165 p.

6. Tretyakov A.V. Formirovanie, zakonomernosti razmeshheniya perspektivy rossypnoy zolotonosnosti Vostoka Kazakhstana [Formation, placement patterns and prospects for placer gold of the East Kazakhstan]. Almaty, Kompleks Publ., 2009. 260 p.

7. Dynn E.I. Geology of gold. London, Charles Griffin and Co., Ltd., 1929. $303 \mathrm{p}$.
8. Boyle R.W. The geochemistry of gold and its deposits (together with a chapter on geochemical prospecting for the element). Bulletin of the Geological Survey, 1979, no. 280, pp. 15-35.

9. Alber I.P. A lithologic-tectonic framework for the metallogenic problems of California. Economic Geology, 1981, vol. 76, no. 4, pp. 765-790.

10. Burnett I.L. Gold mining in California. California-Geology, 1985, pp. 158-196.

11. Tretyakov A.V. Razvitie predstavleniy K.I. Satpaeva o perspektivakh drevnikh rossypey zolota v Kazakhstane [Development of Satbayev's ideas about the prospects of ancient gold placers in Kazakhstan]. Innovatsionnye tekhnologii - klyuch $k$ uspeshnomu resheniyu fundamentalnykh $i$ prikladnykh zadach $v$ rudnom $i$ neftegazovom sektorakh ekonomiki Respubliki Kazakhstan [Innovative technologies are the key to the successful solution of fundamental and applied problems in the ore and oil and gas sectors of the economy of the Republic of Kazakhstan]. Almaty, 2019. Vol. 1, pp. 110-117.

12. Tarr W.A. Introductory economic geology. New York, London, McGraw-Hill Book Company Inc., 1930. 664 p.

13. Geology of Australian ore deposits. Mineralogy and Metallurgy Congress. $2^{\text {nd }}$ ed. Ed. by J. McAndrew. Australia, New Zeeland, Melbourne, 1965. Vol. 1, $235 \mathrm{p}$.

14. Le Barge W., Naumov V.A. New results on the stratigraphy and placer gold potential of central Yukon. Yukon Exploration and Geology, 2008, vol. 1, pp. 1-25.

15. Tretyakov A.V., Peregudov V.V. Novye dannye o zolotonosnosti kaynozoyskikh otlozheniy drevnikh dolin Kalbinskogo rayona [New data on the gold-bearing Cenozoic deposits of the ancient valleys of the Kalba region]. Geologiya i okhrana nedr, 2016, no. 1, pp. 49-53. 
16. Tretyakov A.V., Medeuov M., Alimkhanov M.S. Rossypnaya zolotonosnost tsentralnoy chasti basseyna r. Byukuy (Vostochny Kazakhstan) [Placer gold in the central part of the Bukui River Ba$\sin$ (Eastern Kazakhstan)]. Geologiya i okhrana nedr, 2018, no. 3 (68), pp. 51-57.

17. Patyk-Kara N.G. Mnogoplastovye rossypi prirazlomnykh vpadin [Multilayer placers of fault troughs]. Rossypnye mestorozhdeniya Rossii i drugikh stran SNG [Placer deposits of Russia and other CIS countries]. Moscow, Nauchniy mir Publ., 1997. pp. 92-98.

18. Tleules N.Zh., Slyambaeva A.A., Analieva B.B. Zolotonosnye rossypi Yuzhnogo Altaya i ikh otsenka [Southern Altai gold placers and their evaluation]. Materialy mezhdunarodnoy nauchnoprakticheskoy konferentsii, posvyashchennoy 120-letiyu
K.I. Satpaeva [Materials of the international scientific-practical conference dedicated to the $120^{\text {th }}$ anniversary of K.I. Satpayev]. Ust-Kamenogorsk, 12 April 2019. pp. 160-163.

19. Nokleberg W.J., Bundtzen T.K., Berg H.C. Significant metalliferous lode deposit and placer districts of Alaska. United States Geological Survey Bulletin, 1987, no. 1786, pp. 35-70.

20. Cook D.S., Rao P.D. Distribution, analysis and recovery off in gold from alluvial deposits. Fairbanks, Mineral Industry Research Lab. and Department of Mineral Engineering, Universiti of Alaska, 1973. Report no. 32, 101 p

Information about the authors

Alexander V. Tretyakov, Dr. Sc., senior researcher, Satpaev University.

Saida A. Nigmatova, Dr. Sc., senior researcher, Satpaev University.

Umil B. Gabitova, researcher, Satpaev University. 